\title{
г) Французской.
}

89. Jacobs. Hysteropexie abdominale. (Journal d'accouchements, ноябрь 1893). Притиваніе матки къ передней брюшной стЁнк'

Авторь снова обращаеть вниманіе на неудобства и опасныя осложненія, которыя могуть съ теченіемъ времени произойти посль иперащіи hysteropexiae abdominalis. Онғ доказываеть, что шрикль̆пленная ма:ка мало по малу оттягиваясь отьь брюшной стћнки, образуеть на мьсть прикрыпленія къ посльдней родъ снура, который постепенно можетьь развиться до толщины шальда и сформировать ватћмь ножку въ нъсколько сантиметровъ длины; въ доказательство своего мныннія, онъ представиль Гинекологическому Обществ такого рода ножку, толщиною въ гусиное перо и длиною въ 6 сантиметровъ. Обстоятельства и условія операціи, при которой была добыта эта ножка, представляются въ высокой степени интересными. Больная, 43-хъ л'ьть оть роду, мать многихъ дктей, страдала разнообразными бользненными ирипа:ками. Несчастная женщина въ различное время обращалась за совътомъ къ четыремъ хирургамъ. Первый-призналь нужнымъ сдълать выскабливаніе и ампутацію шейки матки, не принесшія, однако, облегченія больной. Второй хирургь произвель ей гистеропексію, но уменьшенія бользненныхъ припадковъ не произошло. Трегій,-опредъливъ, что бользненныя шрипацки у нея зависять оть есtopiae renalis, произвель операціг нефропексіи, состояніе больной не измънилось къ лучпему. Наконець, четвертый хирургъ констатироваль у бсльной значительную гишертрофію матки, увеличенный объеиъ и кистовидное перерожденіе ея придатковъ и әкстирпироваль пораженныя части черезъ влагалище. Эта посльдыняя операція представлялась крайне сложною и кропотливою по причинь обнаруженной ножки между маткою и брюшною стьнкою, оказывавшей значительное препятствіе къ извлеченію оперируемыхъ частей, тьмъ болье, что она была, какъ оказалось, сроспеюся сь петлею кишечника, почему и была отдылена при шосредств термокаутера. Висемь дней спустя операторь призналь нужнымъ произвести лапаротомію, чтобы эвстирпировать демонстрированную выше п-ромь Јacobs ножку. Больная умерла вскоръ 
оть нефрита, развившагося у нея, по всей вҺроятности, посль ошерапіи нефропексіи.

Въ виду всего изложеннаго д-ръ $M$. Jacobs полагаетъ, что hysteropexia vaginalis duplex по Saenger'y менъе опасна и можеть быть предпринимаема съ такимъ же успьхомъ, почему и совьтуеть предпочитатать еe-hysteropexiae abdominalis.

A. К. Мазуркевичь.

90. Charles. Débridement de la vulve pour eviter la dechirure du perinée. (Journal d'Accouchements, декабрь 1893, 수 29). 0 насьчкахъ на губахъ для предупрежденія разрывовъ промежности.

Авторь возвращается вновь къ вопросу о предупрежденіи разрывовъ иромежности, совбтуя производить насъчки на губахъ. При появившихся показаніяхъ, врачь не долженъ смущаться дьлать надрызы и ограничиваться, какъ многіе предлагаютъ, однимъ или двумя незначительными надрђзами, такь какъ съ одной стороны такими надръзами не предупреждается разрывъ, а съ другой-задвяя сиайка, отдъленная надръзомъ съ двухъ сторонъ, сокращается кзади, дълается мен火е устойчивою и соединеніе ея становится болье затруднительнымъ. Въ виду изложеннаго предпочительнЊе дълать одинъ большой въ 2,3 , даже въ 4 сант. надрђзъ, который по наложеніи швовъ, легко сростается. Изъ этого явствуеть, что цва разръза по $1 \frac{1}{2}$ сантиметра не представляють того значенія какъ одинъ надрғзъ въ 3 сантиметра. Многочисленные же надрқзы, которыхь придерживаются немногіе, должны быть совершенно оставлены. Однако-же и злоупотребленія въ надръзахъ также сл'вуетъ избъгать и не пррестушать должныхъ границъ, при чемь авторь указыв.еть на случай Dürhssen'a, гдњ надръзъ доходиль до 5, 6 сантиметровъ и произвель глубокое раненіе levatoris ani.

Исходя изъ того положенія, что три четверти разрывовъ промежности зависять оть быстраго проръзыванія или выведенія головки, авторъ полагаеть, что предупредить разрывы при давныхъ обстоятельствахъ всецъло зависитъ отъ искуства и ловкости ощерирующаго.

Маленькія головки, по мнънію его, производять чаще разрывы,

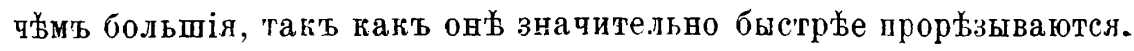
А. К. Мазуркевицг. 